\title{
Batendo palmas a uma só mão: Colonialismo, pós- colonialismo e as fronteiras espácio-temporais do modernismo
}

One Hand Clapping: Colonialism, Postcolonialism, and the Spatio/Temporal Boundaries of Modernism

Applaudir d'une seule main : colonialisme, post-colonialisme et les frontières espacio-temporelles du modernisme

\section{Susan Stanford Friedman}

Tradutor. Inês Martins Ferreira e Rui Pedro Almeida

\section{(2) OpenEdition}

\section{Journals}

Edição electrónica

URL: http://journals.openedition.org/rccs/934

DOI: $10.4000 /$ rccs.934

ISSN: 2182-7435

Editora

Centro de Estudos Sociais da Universidade de Coimbra

Edição impressa

Data de publição: 1 Junho 2006

Paginação: 85-113

ISSN: 0254-1106

Refêrencia eletrónica

Susan Stanford Friedman, «Batendo palmas a uma só mão: Colonialismo, pós-colonialismo e as fronteiras espácio-temporais do modernismo ", Revista Crítica de Ciências Sociais [Online], 74 | 2006 colocado online no dia 01 outubro 2012, criado a 19 abril 2019. URL : http://journals.openedition.org/ rccs/934; DOI : 10.4000/rccs.934

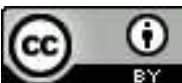




\section{Batendo palmas a uma só mão: Colonialismo, pós-colonialismo e as fronteiras espácio-temporais do modernismo}

O ensaio põe em causa a ideia dominante de que o Ocidente inventou a modernidade e o modernismo, enquanto o resto do mundo se limitou a imitar o Ocidente mediante formas dele derivadas. Reflecte sobre as paisagens urbanas de Xangai e Manhattan para desfazer a equivalência comummente aceite entre modernização e ocidentalização, e socorre-se da história mundial comparada e dos estudos pós-coloniais para sugerir novos modos de pensar os limites espácio-temporais do modernismo/modernidade. Põe em paralelo as traduções de gravuras japonesas por Cassatt, as adaptações de artefactos africanos por Picasso e a reescrita de Conrad pelo escritor sudanês Tayeb Salih para demonstrar a existência de fluxos culturais transcontinentais na formação de diferentes modernismos.

... parece prematuro, se não mesmo um gesto claramente etnocêntrico, anunciar genericamente o fim do modernismo até como época, mas sobretudo como atitude ou como ethos, numa altura em que, um pouco por toda a parte, os povos não-ocidentais começam a viver de uma maneira crítica as suas próprias modernidades híbridas.

Dilip PARAmeshwar GaONKar (2001: 14)

É possível ouvir o som de uma só mão batendo palmas na floresta da discussão?

\section{Introdução}

Antes de tentar responder à pergunta acima, gostaria de começar com uma história. Estava em Xangai, em Julho de 2001, sentada em redor de uma mesa de jantar com alguns docentes universitários e com estudantes de pós-graduação da Universidade de Fudan. A conversa foi ter às recentes mudanças ocorridas em Xangai. Desde 1992 que a cidade vem sofrendo aquela que é provavelmente a mais rápida transformação urbana da História. À excepção do bairro histórico do Bund, situado junto ao rio, e que, sendo uma das antigas áreas ainda exploradas por estrangeiros na zona, foi 
deixado intacto por causa dos turistas, a cidade de Xangai foi completamente demolida. Por todo o lado existem agora edifícios altos - edifícios altos para os negócios, edifícios altos para habitação, edifícios altos para escolas, e mercados, e lojas. Existem ainda alguns edifícios encimados por aquilo a que o meu amigo, o Professor Liu Dong da Universidade de Pequim, chama "chapéus chineses". A quantidade de auto-estradas que cruzam a cidade, com complicados sistemas de rampas e viadutos, ultrapassa até a de Los Angeles, e um novo monocarril de alta velocidade - o comboio mais rápido do mundo - circula rápido bem por cima das auto-estradas, numa mancha de néons que o fazem parecer um teletransportador de pessoas saído de um filme de ficção científica.

Inesperadamente, uma das alunas - alta e esguia como uma vara, e com um olhar intenso - irrompeu num discurso apaixonado, a voz quase embargada pela emoção e as lágrimas. Disse que a China estava a perder a alma a troco de uma comercialização desenfreada e que a "ocidentalização" estava a conduzi-la para a ideia de que "o dinheiro é tudo". Não era o Starbucks ou o McDonald's que a preocupavam. O que a enfurecia era o facto de a ocidentalização ter deitado abaixo todos os bairros de Xangai. E ainda havia mais: disse que adorava a música de Beethoven e de Brahms, mas que não conseguia entender a música chinesa. Acrescentou que era importante estudar Platão e Aristóteles, Hobbes e Locke. Mas que parte das suas aulas de Ciências Políticas se consagrava ao estudo de pelo menos um pensador da política chinês? Porque seria a China incapaz de se modernizar como fez o Japão - construindo a segunda maior economia mundial mas salvaguardando as suas diferenças, particularmente a sua identidade cultural, tão distinta do resto do mundo? Olhei em redor, para uma mesa de rostos espantados. Ninguém disse uma palavra.

Decidi tentar descomprimir a situação partilhando algum do choque cultural que eu própria senti em Xangai - a minha sensação de uma cidade construída à imagem de uma estação espacial, especialmente Pudong, a nova linha de horizonte de Xangai, do outro lado do rio, que há uns meros dez anos só tinha campos. Xangai fazia com que Manhattan - com as suas ruas de merceeiros coreanos e italianos, os seus cafés, padarias e pizzarias, os seus pequenos bairros e parques, e homens a jogar damas no Washington Square Park - parecesse provinciana, saída de uma espécie de vórtice de tempo, com cem anos de atraso. Respondi-lhe que no "Ocidente" nunca tinha visto nada como Xangai. Parecia uma cidade futurista, diferente de tudo quanto existe nos E.U.A., diferente de tudo quanto existe na Europa, particularmente na Europa, onde o passado parecer estar sempre ao virar da esquina, em cada edifício conservado, como as colunas antigas que despontam por 
entre as árvores e o trânsito da Roma de hoje. Disse-lhe o que tinha sentido ao regressar a Hong Kong, ao bairro onde vivera há 30 anos. Todos os mercados ao ar livre de Hong Kong tinham desaparecido. Não via lojas onde as pessoas pudessem comprar comida. Visitei alguns projectos de habitação estatais muito apreciados, um complexo de edifícios alto contendo tudo o que agora, nas ruas, havia desaparecido da vista - o mercado de produtos frescos no primeiro andar, o mercado de secos no segundo, e as associações comunitárias no terceiro. Os verdejantes arrozais da parte continental, logo ali às portas da cidade, ainda lá estavam, mas por todo o lado brotavam dezenas de enormes edifícios de apartamentos, ligados por estradas que atravessavam os campos verdes, sem outros edifícios à vista. Da janela do prédio que visitei, conseguia ver uns 50 edifícios. Cada um alberga cinco mil pessoas e contém uma escola própria, bem como restaurantes, piscina, associações comunitárias e serviços: aldeias verticais edificadas no céu.

Nada disso existe no "Ocidente", disse eu à aluna em Xangai. Nada. Porquê chamar "ocidentalização" a este novo modo de vida que eu agora via em Xangai e em Hong Kong? Ela não soube responder e, além do mais, não acreditou em mim. Embora - admiti eu - os arranha-céus tenham surgido inicialmente no Ocidente, fiz notar que os três edifícios mais altos do mundo se encontram agora em Taiwan e na Malásia. E Paris não permite um único arranha-céus que seja. De nada valeu. Tentei então uma nova abordagem. Lembrei-lhe que os estudiosos da cultura do quotidiano afirmaram que uma das mudanças mais profundas dos últimos 35 anos foi a forma como as pessoas hoje em dia ouvem música - caminhando de auscultadores nos ouvidos, sintonizadas num mundo muito pessoal de ritmos e letras. Dantes, a música era, geralmente, uma experiência vivida em comunidade, mas agora as pessoas podem optar pela privacidade. De onde surgiu esta forma "moderna" de experiência musical?, perguntei. "Do Ocidente", respondeu. Não, disse-lhe. O walkman veio do Japão. A Sony foi pioneira a nível mundial no fabrico e comercialização dos aparelhos electrónicos de uso comum. A nova era da globalização é impensável sem as inovações vindas da Ásia, afirmei. A construção da "modernidade" dos nossos dias não pode ser reduzida à fórmula "Ocidentalização do mundo não-ocidental".

Ela não ficou convencida. O "Ocidente", lugar onde nunca tinha estado, permanecia no seu horizonte como um espaço monolítico a ser desejado e desprezado, ansiado e temido. Não acreditava que a inovação na modernização pudesse vir de qualquer lado que não fosse o Ocidente. Arredada da História do seu país por efeito da devastação decorrente da Revolução Cultural, pouco sabia acerca do domínio da ordem mundial exercido pela China antes de 1500. Nunca tinha ouvido falar da cidade de Guangzhou, a sul de 
Xangai, outrora a maior cidade portuária do mundo, onde eu tinha acabado de ver o esqueleto de um inovador navio chinês, com mais de 30 metros de comprimento, do período da dinastia Ming (por volta do século XIII) e onde caminhara sobre a ponte de pedra do século VIII cuja tecnologia flutuante fazia desta a primeira ponte sobre o mar de toda a História. As ruínas de uma mesquita do século VII construída por mercadores árabes ainda se encontram de pé nessa buliçosa e moderna cidade que adoptou o arco islâmico como marca identificativa da sua arquitectura. Diz-se que Marco Pólo saiu da China por Guangzhou, e há um pergaminho de grandes dimensões e proveniente desse período que mostra um porto com centenas de mastros e um conjunto amplo de embarcações de todos os cantos do mundo, incluindo da Europa. A jovem também não sabia que, no período final da dinastia Ming, no século XV, o imperador ordenou a destruição dos projectos de todos os seus navios de grande porte e fechou as portas da China ao comércio global, de forma a preservar a pureza da cultura chinesa.

Conto esta história como ponto de partida para o objectivo do presente simpósio, que vejo como sendo o de pluralizar o modernismo, isto é, entender os modernismos num quadro global. Para o conseguir, devemos romper com a poderosa ideia de que é ao eurocentrismo hoje generalizado que se devem a origem e o alastramento da modernidade, da modernização e do modernismo. Devo dizer, antes de mais, que faço distinção entre estes três termos ligados entre si. Assim, utilizo modernidade para me referir a uma condição histórica de ruptura radical num espectro de indícios sociais associado à dimensão experiencial de mudança acelerada - aquilo a que chamo fenomenologia do novo e do agora; utilizo modernização para me referir ao processo histórico no sentido da modernidade; e utilizo modernismo para me referir às expressões estéticas e filosóficas da modernidade, com especial destaque para aquelas que evidenciam auto-reflexividade e uma tentativa de encontrar novas formas de percepção e de representação em consonância com a ruptura. Deste modo, vejo o modernismo como sendo as formas criativas de expressividade dentro da modernidade, actividades que não só reflectem a condição da modernidade como também a possibilitam. $\mathrm{Na}$ minha perspectiva, o modernismo umas vezes adere à modernidade e, outras vezes, resiste-lhe criticamente, mas em todo o caso é sempre uma parte integrante e significativa da modernidade e não separada dela. ${ }^{1}$

\footnotetext{
${ }^{1}$ Os sociólogos empregam com frequência o termo modernismo para se referir à modernidade enquanto ideologia ou sistema de crenças (normalmente enraizadas no Iluminismo ocidental) que promove a modernidade enquanto progresso; inclusivamente, usam a expressão Alto Modernismo para fazer referência a uma formação ideológica particularmente intensa aliada ao poder do Estado e até mesmo ao totalitarismo (ver, por exemplo, Scott, 1998).
} 
Além disso, abordo toda esta questão dos três termos com um cepticismo saudável no que diz respeito à própria ideia de mudança histórica. Como escrevi noutra altura, o conceito de modernidade gera o seu suposto contrário - a tradição - e pressupõe uma "tradição" relativamente estática em relação à qual "a modernidade" representa um corte radical (Friedman, 2001). Plus ça change, plus ça même. Quanto mais as coisas mudam, mais fica tudo na mesma. O conceito de modernidade obscurece as continuidades históricas e a dificuldade de operar mudanças efectivas. É certo que modernidade designa situações históricas, mas designa igualmente um estado de espírito, uma consciência de ruptura, uma crença numa ruptura com o passado, e também uma orientação futura, que frequentemente alia o fervor utópico a uma nostalgia distópica pelo passado imaginado e a uma amnésia cultural generalizada, uma vontade de esquecer.

\section{Da "modernidade" eurocêntrica às "modernidades" policêntricas}

Para atacar a questão do eurocentrismo, é preciso não só abandonar a acentuação generalizada do plano temporal, mas também compensar tal tendência tomando agora como quadro de análise o plano espacial. Necessitamos de uma gramática espacial interdisciplinar que dê particular importância aos conceitos de zona de contacto, encontro intercultural, hibridação, transculturação, indigenização, bem como ao tráfego global de bens, ideias, povos e práticas culturais. Não concordo com Dilip Parameshwar Gaonkar e outros que distinguem marcadamente a "modernização social", por um lado, e por outro uma "identidade cultural [que] ... foi crescendo em oposição" a ela (Gaonkar, 2001:2). A oposição que este autor tão vincadamente postula espelha a separação entre as ciências sociais e as Humanidades. Necessitamos de uma abordagem integrada e interdisciplinar que reconheça o modo como o social e o cultural se entrelaçam em diferentes modernidades, modernizações e modernismos de diferentes épocas e lugares.

O eurocentrismo generalizado existente nos estudos do modernismo tende a dividir o mundo em categorias binárias, como sejam Primeiro Mundo/Terceiro Mundo, Ocidente/Oriente, Norte/Sul, ou centro/periferia, ou seja, tudo formas de opor o Ocidente - o Oeste - e o Resto. Divisões como estas ignoram a diversidade inerente a qualquer lugar, bem como as estratificações de que todas as sociedades são feitas. Também partem, muitas vezes, do princípio de que a modernidade que caracteriza o Ocidente é efectivamente a modernidade primeira e definitiva, sendo as formas subsequentes de modernidade, desenvolvidas noutras partes do mundo, resultado da difusão a partir do centro para as periferias. Em The Colonizer's Model of the World (O modelo que o colonizador tem do mundo), o geógrafo J. M. 
Blaut chama a esta perspectiva difusionismo europeu, caracterizando-o como um sistema de crenças que se desenvolveu no século XIX no espectro das disciplinas e na cultura de massas, em conjunto com o colonialismo europeu e com a hegemonia americana que se irá verificar no século XX. Esta crença, ignorando tudo quanto o Ocidente foi buscar às civilizações islâmica, mongólica, chinesa, indiana e outras, pressupõe normalmente o excepcionalismo europeu, quer dizer, a ideia de que a chamada ascensão do Ocidente a partir de 1492 se tornou possível porque este estava mais avançado do que as outras sociedades da época ou então porque as suas características internas lhe permitiram inventar, por si só, a modernidade. Nas palavras daquele autor:

Os europeus são vistos como os "fazedores da História". A Europa está eternamente a avançar, a progredir e a modernizar-se. Quanto ao resto do mundo, avança arrastadamente ou estagna: é a "sociedade tradicional". Assim, o mundo tem um centro geográfico permanente e uma permanente periferia: um Dentro e um Fora. O Dentro comanda, o Fora segue à distância. O Dentro busca a inovação, o Fora a imitação. Esta crença é o difusionismo, ou, mais precisamente, o difusionismo eurocêntrico. É uma teoria sobre a forma como os processos culturais tendem a movimentar-se ao longo do planeta como um todo. [...] A Europa é a fonte da maioria das difusões; a não-Europa é o receptor. (Blaut, 1993: 1)

O poder desta narrativa é tal que ela é usada em todo o espectro político, desde a direita à esquerda. Na sua influente obra de 1994, O choque das civilizações e a mudança na ordem mundial, o politólogo Samuel P. Huntington, por exemplo, escreve o seguinte:

O Ocidente distingue-se claramente de todas as outras civilizações que alguma vez existiram na medida em que teve um impacto avassalador em todas as outras civilizações existentes desde o século XVI. Também instaurou os processos de modernização e de industrialização que vieram a estender-se a todo o mundo e, em resultado desse facto, as sociedades de todas as outras civilizações têm vindo a tentar acertar o passo com o Ocidente no que diz respeito a riqueza e modernidade. (Huntington, 1994: 302)

O que Huntington teme é que o contacto excessivo entre o Ocidente, ou Oeste, e o Resto - uma expressão letal de que ele próprio foi o criador - venha a envenenar o Ocidente e causar a sua queda. Por outro lado, no outro extremo do espectro político, o sociólogo Immanuel Wallerstein, proponente da teoria do sistema-mundo na década de 70 do século XX e 
o mais influente dos seus praticantes, argumenta que o Ocidente inventou a modernidade quando "a economia-mundo da Europa quinhentista se tornou irremediavelmente capitalista": "o vírus propagou-se rapidamente, revelando-se invulnerável às posteriores tentativas de inverter os seus efeitos" (Wallerstein, 1997: 105). Numa oposição simétrica a Huntington, Wallerstein vê o Ocidente como sendo a fonte de poluição ou de doença, e não como sua potencial vítima. Mas, tal como Huntington, Wallerstein atribui à Europa a ascensão do capitalismo, facto que lhe serve de metonímia para a própria modernidade.

O cri de coeur da estudante de Xangai contra uma modernidade ocidentalizada marcha ao som da música anti-Ocidente de Wallerstein. Surpreendentemente, no entanto, ele é também inteiramente compatível com a posição de Huntington. Tal como eles, ela evidencia o poder da narrativa que o Ocidente construiu e espalhou acerca da sua própria invenção sui generis da modernidade e da sua difusão por outras paragens. Que alguns relatos sejam celebratórios enquanto outros são condenatórios não muda o enredo, apenas o ponto de vista em relação a ele.

Contudo, há um crescente coro de vozes que está a tentar abrir novos horizontes para além do difusionismo eurocêntrico, defendendo a noção de modernidades múltiplas ou alternativas. ${ }^{2}$ No seu livro Unthinking Eurocentrism - um título que contém um belíssimo trocadilho alusivo à in-consciência da ideologia e à necessidade de um pensamento revisionista ${ }^{3}-$, Ella Shohat e Robert Stam, por exemplo, fustigam em particular a esquerda devido à sua vitimologia narcisista:

Nem tão-pouco acreditamos no narcisismo europeu de sentido inverso, que acusa a Europa de ser a fonte de todos os males sociais do mundo. Uma abordagem como esta continua a ser eurocêntrica [...] além de que isenta de quaisquer responsabilidades as elites patriarcais do Terceiro Mundo. Tal "vitimologia" reduz a vida não-europeia a uma reacção patológica à penetração ocidental. Ou seja, limita-se a inverter os argumentos colonialistas. (Shohat e Stam, 1994: 3)

\footnotetext{
${ }^{2}$ A obra de 1987 Modernism and the Harlem Renaissance, de Houston A. Baker, Jr, foi um primeiro e importante alerta para o reconhecimento de que a modernidade e, consequentemente, o modernismo do afro-americano tem de ser periodizado de modo diferente do da Euro-América. A teoria pós-colonial da última década do século $\mathrm{XX}$ apresentou sólidos argumentos para que se reconhecesse a distinta modernidade das nações colonizadas e emergentes do século XX (ver, por exemplo, Appadurai, Chakrabarty, Chatterjee, e Gaonkar). Outros autores, incluindo os estudiosos da História mundial, os antropólogos e os teóricos da cultura e da sociedade, também começaram a reivindicar o reconhecimento de modernidades mais antigas e alternativas (ver, por exemplo, Abu-Lughod, Blaut, Eisenstadt e Schluter, Frank, Friedman, McNeill, Mitchell, Sanderson, Tsing e Weatherford).

3 Simultaneamente "Des-pensar o Eurocentrismo" e "Eurocentrismo Impensado" [N. do T.].
} 
Em vez de louvar ou de zurzir o Ocidente, Shohat e Stam recomendam uma abordagem "policêntrica" que tenha em conta múltiplos e distintos centros interagindo uns com os outros numa paisagem global. Apelam a uma "relativização" ou um descentramento do Ocidente, enquanto Dipesh Chakrabarty propõe um conceito correlato, ao qual chama "provincianizar a Europa". Em Modernism and the Harlem Renaissance, Houston Baker, Jr. propôs algo semelhante ao considerar as heterogeneidades no interior do próprio Ocidente, argumentando que, para o afro-americano, a modernidade tem início com o levantamento da escravatura, a imposição do regime de apartheid de Jim Crow, iniciado na última década do século XIX com o caso Plessy contra Fergusson, e os diferentes protótipos de resistência protagonizados por Booker T. Washington e W. E. B. DuBois. Baseando-se na tese de C. L. R. James em The Black Jacobins (Os Jacobinos negros), Paul Gilroy faz recuar ainda mais as origens da modernidade negra nas Américas: com efeito, situa-as nas rupturas radicais da chamada Passagem Atlântica (a "Middle Passage") e da escravidão, que fizeram dos Africanos transplantados à força da Europa para o Novo Mundo os primeiros sujeitos "modernos" (Gilroy, 1993: 221).

Deslocando o debate sobre a modernidade para a longue durée da História - a História Mundial considerada ao longo dos milénios -, os historiadores e os teóricos do sistema-mundo estão hoje a repensar a "ascensão do Ocidente" em função de uma paisagem temporal que reconhece a preexistência de uma ecúmena de tráfego comercial, demográfico e cultural, bem como uma brutal história de conquista e de impérios que propiciou encontros interculturais de grande intensidade, inovações tecnológicas, e alterações culturais extremamente rápidas e generalizadas. ${ }^{4}$ Shmuel $\mathrm{N}$. Eisenstadt e Wolfgang Schluter, organizadores de dois números especiais da revista Daedalus sobre "As Primeiras Modernidades" e "Modernidades Múltiplas", descrevem o modo como "foram surgindo várias civilizações modernas, todas elas multicentradas e heterogéneas, todas elas geradoras da sua própria dinâmica" (Eisenstadt e Schluter, 1998: 3). Segundo estes autores, diferentes sociedades, expostas umas às outras, foram-se desenvolvendo através da "apropriação criativa" das ideias umas das outras. Ao contrário do que previram Marx e Weber, esta "globalização de redes culturais e de canais de comunicação" gerou "múltiplas e diferentes modernidades", e não uma convergência resultante num "mundo moderno uniforme" (Eisenstadt e Schluter, 1998: 5).

\footnotetext{
${ }^{4}$ Ver, em especial, Abu-Lughod, Eisenstadt e Schluter, Frank, Sanderson, e Weatherford.
} 
Que pensaria a estudante de pós-graduação de Xangai, pergunto-me, acerca do argumento de Andre Gunder Frank sobre a modernidade, proposto em ReOrient: Global Economy in the Asian Age, onde o autor atribui a ascensão do Ocidente à súbita entrada do ouro e da prata do Novo Mundo, que lhe permitiu pela primeira vez competir no mercado mundial dominado pelos Chineses? Frank sugere que o domínio ocidental é temporário, tendo sido precedido pela importância das civilizações asiáticas anteriormente a 1500, e devendo seguir-se-lhe uma nova ascensão da Ásia no decurso do século XXI. Desta perspectiva, a Xangai de hoje não constitui uma ocidentalização mas antes o restabelecimento da liderança da China na nossa paisagem global.

Mais do que qualquer outro factor, a obra Genghis Khan and the Making of the Modern World (Gengiscão e a construção do mundo moderno), de Jack Wheatherford, foi, na minha opinião, a principal causa do estilhaçamento do paradigma. Num império que ainda hoje continua a ser o mais vasto da História, a modernidade mongol dos séculos XIII e XIV ligou rapidamente toda a região da Afro-Eurásia; estimulou amplas trocas comerciais; expandiu tecnologias como os caracteres móveis, a pólvora e o instrumentário de apoio à navegação; inventou a moeda-papel e instituiu um sistema de crédito e de acções; estabeleceu uma "lei universal" à qual até os governantes estavam sujeitos; proclamou a liberdade religiosa e recusou a criação de uma religião do Estado; aboliu a tortura, o rapto de mulheres e a escravatura; criou o ensino universal; criou uma classe de profissionais isenta de impostos, constituída, entre outros, por professores, escolares e advogados; e levou a matemática indiana e árabe até à China e a medicina chinesa até ao Ocidente.

Muito mais poderia dizer-se acerca dos Mongóis como motores da modernidade de que a ascensão do Ocidente viria a depender. Mas o mais importante é que uma abordagem policêntrica da modernidade exige, em primeiro lugar, um repensar essencial daquilo mesmo que queremos dizer com modernidade. Atendendo a que os Mongóis eram nómadas, temos de rever a associação habitualmente feita entre modernidade e metrópole. A modernidade pode assumir formas quer nómadas quer metropolitanas. Também pode ser arquipelágica, baseada no contacto por mar, como sucede em regiões como o Sudeste Asiático ou as Caraíbas. Dentro deste panorama de possibilidades, a modernidade ocidental é uma entre muitas. Certamente uma modernidade importante pelo menos ao longo de três centenas de anos, mas longe de ser a única modernidade e longe de ser a bitola pela qual todas as outras modernidades deverão ser julgadas. Como diz Gaonkar em Alternative Modernities, “a modernidade não é só uma, mas várias" (Gaonkar, 2001: 17). 
Em Transnational Modernism ("Modernismo transnacional"), sugeri o seguinte esquema com vista a captar de forma paratáctica aquilo a que Gaonkar chama uma "penumbra de semelhanças" no espectro de modernidades múltiplas.

A Modernidade como Matriz de Mudanças Convergentes:

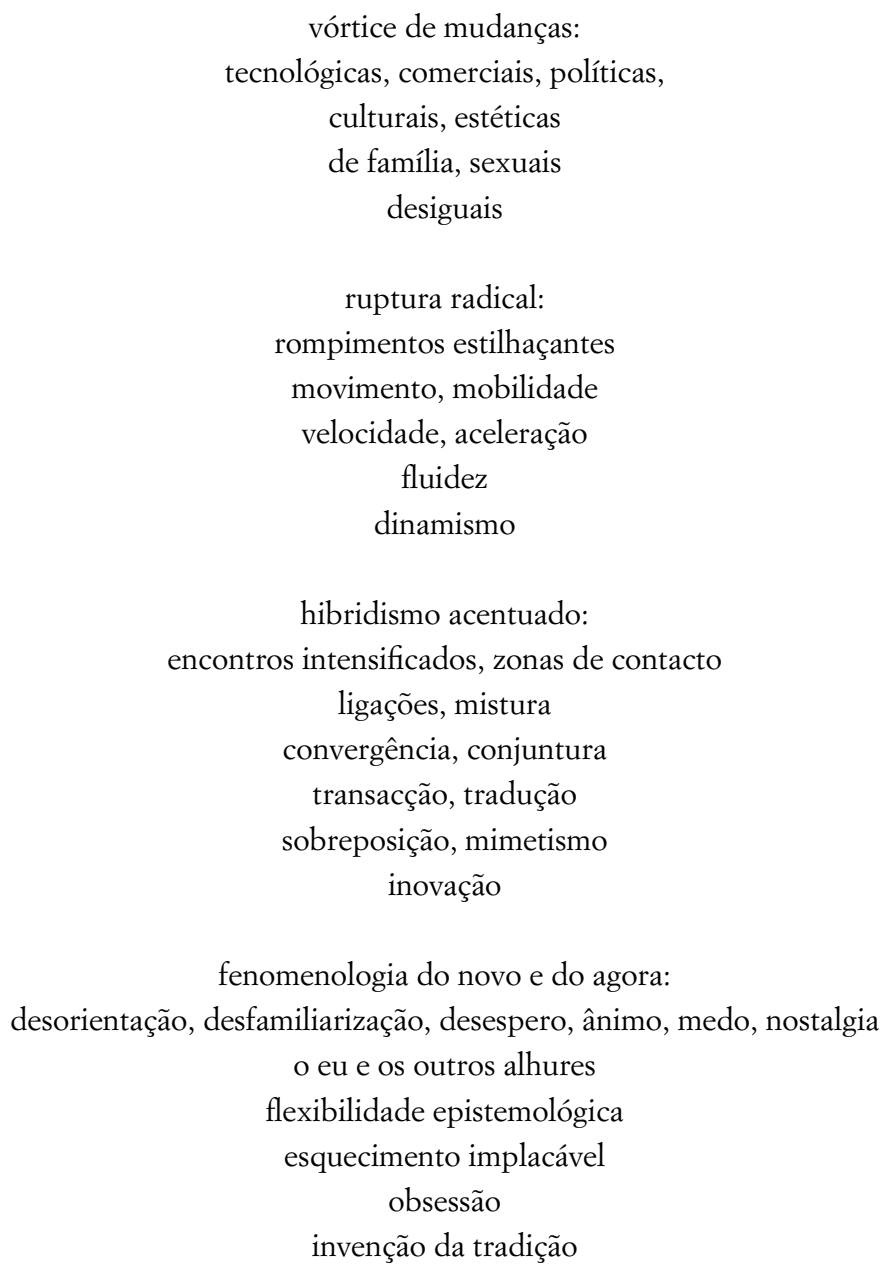

\section{Do modernismo eurocêntrico aos modernismos}

Para pluralizar o modernismo, necessitamos de repensar as noções de fronteiras espaciais e temporais do modernismo. A periodização dominante do modernismo encerra em si também o pressuposto de fronteiras espaciais 
que não é não abertamente reconhecido. Atente-se na declaração fundadora da Modernist Studies Association (Associação de Estudos do Modernismo), ainda patente na página web desta dinâmica e jovem organização, actualmente já no seu sexto ano de existência:

A Modernist Studies Association dedica-se ao estudo das artes no seu contexto social, político, cultural e intelectual, desde os finais do século XIX até meados do século XX. (http://msa.press.jhu.edu /; sublinhado meu $)^{5}$

Esta declaração - mais as suas balizas, situadas por volta da última década do século XIX e da década de 40 do século XX -, configura tacitamente uma política espacial que privilegia o modernismo anglo-americano e ignora a natureza policêntrica e plural dos próprios modernismos europeus, já para não mencionar os que são exteriores à Europa. São muitos os críticos, por exemplo, que iniciam as suas genealogias do modernismo com o flâneur cosmopolita de Baudelaire a partir da década de 40 do século XIX (Benjamin, 1968: 155-200; Berman, 1988: 131-72; Nichols, 1995: 1-23, Gaonkar, 2001: 4-6). As fronteiras temporais do modernismo defendidas pela MSA não funcionam sequer no que ao modernismo ocidental diz respeito.

A data da MSA geralmente aceite como fim do modernismo tem um efeito ainda mais prejudicial nas fronteiras espaciais. Tal periodização amputa a acção dos escritores, artistas, filósofos e outros produtores culturais do mundo pós-colonial emergente, na altura exacta em que novas modernidades estão a formar-se fora do Ocidente: a independência da Índia, por entre a mortandade devastadora e a deslocação de milhões de pessoas, em consequência da Partilha do subcontinente no ano de 1947; a nova independência do jugo colonial por parte das nações caribenhas e africanas, por volta da mesma data; as lutas em torno da modernidade hoje em dia travadas no mundo islâmico.

Declarar que o fim do modernismo se dá por volta de 1950 é como tentar ouvir uma só mão batendo palmas. Os modernismos das nações emergentes são essa outra mão que devemos escutar de forma a ouvir algum bater de palmas que seja. Se aceitarmos que o colonialismo faz parte da modernidade ocidental, essencial à sua formação desde o século XVI até ao século XX, não devemos fechar as portas ao modernismo sem que antes as vozes criativas das colónias tenham a sua oportunidade de falar. Os seus movimentos nacionalistas e a sua libertação das dimensões políticas da governação colo-

\footnotetext{
5 Ver igualmente Modernism, 1890-1930, de Malcolm Bradbury e James McFarlane, onde os autores apontam o ano de 1930 como o do fim do Modernismo.
} 
nial são decisivos para a história das respectivas modernidades. Por isso, as forças criativas existentes nessas modernidades estão empenhadas em gerar modernismos que acompanhem as suas modernidades específicas. Chamar "pós-modernas" às suas artes pós-libertação - como muitas vezes sucede é não entender, de todo, a questão. Dizer múltiplas modernidades é o mesmo que dizer modernismos múltiplos. E dizer modernismos múltiplos é o mesmo que reespacializar e reperiodizar o modernismo. ${ }^{6}$

A centralidade do colonialismo e do pós-colonialismo no século XX exige uma nova geografia da modernidade e do modernismo, baseada numa compreensão daquilo a que Edward Said chamou "teoria em viagem", a que o antropólogo James Clifford se refere como "culturas em viagem" e que o poeta e teórico caribenho Eduard Glissant designa uma "poética de relação" geradora de "creolitê" ou da "incomensurável interpenetração de culturas" (Glissant, 1997: 138). Em vez de propor um mosaico de diferentes modernismos, cada um deles separado de todos os outros por barreiras estanques de delimitação geopolítica e cultural em toda a face da terra, vejo as fronteiras entre os múltiplos modernismos como sendo porosas e permeáveis, promovendo o confronto entre o eu e o outro e misturas que mutuamente se vão constituindo. Esta geografia de mobilidade e de interculturalidade não é uma fantasia utópica de uma integração pacífica, mas antes reconhece que as zonas de contacto entre as culturas implicam muitas vezes a violência, a conquista, a humilhação e a desigualdade. Tal geografia deve, por isso, ter em conta a diversidade da distribuição de poder, mas também deve recusar a vitimologia. Deve assumir que nas zonas de encontro existe capacidade de acção de todas as partes. Não autonomia, pois esta sugere a liberdade de agir sem o impedimento dos outros, mas uma efectiva capacidade de acção, com o que pretendo significar o impulso para nomear a identidade colectiva própria e negociar as condições da História, por mais duras que sejam.

Em termos estéticos, esta nova geografia implica uma reescrita radical daquilo a que os críticos chamaram o internacionalismo do modernismo: o seu polilinguismo e policulturalismo, o seu antinacionalismo e o seu acolhimento do Outro não-ocidental como meio de revitalizar as várias esterilidades do Ocidente. Este conceito prevalecente de internacionalismo modernista retrata os artistas do nosso Oeste como os inovadores e as culturas do Resto como tribais e tradicionais, funcionando como matéria-prima para apropriação criativa e transmutação naquilo que é o génio da arte moderna.

\footnotetext{
${ }^{6}$ Para um conjunto de críticos que detectaram modernismos fora do Ocidente e/ou fora das fronteiras temporais convencionais, ver, por exemplo, Makdisi, 1995; Wang, 1997; Joshi. 2002; Rao e Shulman, 2002; Friedman, 2003.
} 
Em vez deste modelo de centro/periferia, a nova geografia do modernismo deve estabelecer muitos centros pelo globo fora, centrando-se no tráfego cultural que os liga e interpretando os circuitos de influência e de transformação recíprocas.

As culturas em viagem e interpenetradas não são unidireccionais mas multidireccionais; não são influências lineares, mas recíprocas; são assimilações não passivas, mas sim activamente transformativas, baseadas numa fusão entre adopção e resistência. A modernidade e o modernismo intensificam este processo contínuo de mudança e de troca cultural. Adaptando as bem conhecidas palavras-chave dos estudos culturais propostas por Raymond Williams, na obra que dá exactamente pelo título Keywords, elaborei uma lista com muitas das palavras-chave da interculturalidade actualmente em uso.

\section{Interculturalidade: Substantivos}

$\begin{array}{lll}\text { abastardamento } & \text { corte e colagem } & \text { erosão } \\ \text { absorção } & \text { cosmopolitismo } & \text { extrapolação } \\ \text { acomodação } & \text { crioulização } & \\ \text { aculturação } & \text { cruzamento } & \text { filiação } \\ \text { adaptação } & \text { fricção } \\ \text { adopção } & \text { "desculturação" } & \text { fusão } \\ \text { aliança } & \text { desdobramento } & \\ \text { amalgamação } & \text { deslocação } & \text { hibridação } \\ \text { androginia } & \text { devoração } & \text { homogeneização } \\ \text { antropofagia } & \text { diferenciação } & \\ \text { apropriação } & \text { diluição } & \text { imitação } \\ \text { assimilação } & \text { distorção } & \text { impacto } \\ \text { canibalização } & \text { dívida } & \text { importação } \\ \text { choque } & & \text { imposição } \\ \text { circulação } & \text { eco } & \text { improvisação } \\ \text { colaboração } & \text { elaboração } & \text { incorporação } \\ \text { coligação } & \text { elipse } & \text { indigenização } \\ \text { colisão } & \text { empenhamento } & \text { influência } \\ \text { comércio } & \text { empréstimo } & \text { ingestão } \\ \text { compromisso } & \text { emulação } & \text { integração } \\ \text { contaminação } & \text { encontro } & \text { intercâmbio } \\ \text { cooptação } & \text { endividamento } & \text { interculturalidade } \\ \text { cópia } & \text { entrelaçamento } & \text { interferência } \\ \text { enxerto } & \text { interiorização }\end{array}$




$\begin{array}{lll}\text { interpelação } & \text { penetração } & \text { subversão } \\ \text { interpenetração } & \text { pidgin } & \\ \text { interpolação } & \text { poluição } & \text { teleopoesis } \\ \text { intertextualidade } & \text { pushmi-pullyu } & \text { tomada de empréstimo } \\ \text { intervenção } & & \text { tradução } \\ \text { inversão } & \text { realinhamento } & \text { tráfego } \\ & \text { recepção } & \text { transcodificação } \\ \text { localização } & \text { recombinação } & \text { transculturação } \\ \text { mediação } & \text { reconfiguração } & \text { transferência } \\ \text { metamorfose } & \text { reelaboração } & \text { transfiguração } \\ \text { mimetismo } & \text { reenquadramento } & \text { transformação } \\ \text { mímica } & \text { reescrita } & \text { transmissão } \\ \text { miscigenação } & \text { refracção } & \text { transmutação } \\ \text { mistura } & \text { reinvenção } & \text { transplante } \\ \text { modificação } & \text { reversão } & \text { transposição } \\ \text { morfoseamento } & \text { revisão } & \text { trasfego } \\ \text { mutação } & \text { roubo } & \text { tresleitura } \\ \text { nativização } & \text { troca } \\ \text { naturalização } & \text { selecção } & \\ \text { negociação } & \text { significação } & \text { união } \\ \text { paródia } & \text { sincretismo } & \\ & \text { síntese } & \text { vernaculização } \\ & \text { submersão } & \end{array}$

Estas palavras-chave agrupam-se, por sua vez, em vários tipos de metáforas: biológicas, comerciais, políticas, de representação, culturais e corporais.

\section{Interculturalidade: Metáforas}

Biológicas: adaptação, adopção, androginia, abastardamento, circulação, contaminação, diluição, erosão, fricção, enxerto, hibridação, miscigenação, mestiçagem, metamorfose, mutação, naturalização, poluição, selecção, transplantação, transmutação

Corporais: absorção, antropofagia, canibalização, submersão, incorporação, ingestão

Comerciais: circulação, comércio, dívida, empréstimo, endividamento, importação, incorporação, roubo, tomada de empréstimo, tráfego, troca, união

\footnotetext{
$\overline{7}$ Literalmente, "empurra-me/puxo-te" [N. do T.].
} 
Políticas: acomodação, aliança, apropriação, coligação, colaboração, compromisso, cooptação, cosmopolitismo, empenhamento, encontro, filiação, impacto, imposição, influência, interferência, interpelação, interpenetração, intervenção, mediação, negociação, penetração, realinhamento, subsunção, subversão

Culturais: aculturação, adaptação, antropofagia, assimilação, canibalização, choque, colisão, cruzamento, "desculturação", diferenciação, encontro, fricção, homogeneização, hibridação, indigenização, integração, intercâmbio, interculturalidade, localização, mistura, nativização, naturalização, sincretismo, transculturação, vernaculização

De representação: cópia, corte e colagem, desdobramento, diferenciação, distorção, eco, elaboração, imitação, improvisação, influência, intertextualidade, mimetismo, mímica, morfoseamento, paródia, pidgin, recepção, recombinação, reconfiguração, reenquadramento, reescrita, refracção, reelaboração, reinvenção, reversão, revisão, significação, transcodificação, tradução, transposição, vampirização, vernaculização

O termo que aqui desejo destacar é indigenização - uma forma de tornar nativo algo que vem de outro lugar. A indigenização pressupõe uma afinidade de algum tipo entre as práticas culturais de outro lugar e as do espaço indigenizador. Um terreno hostil não permite a transplantação; inversamente, as práticas que aí ganham raiz são modificadas em virtude do próprio processo. A antropóloga Anna Tsing compara esta relação paradoxal à "fricção" que permite o movimento: a resistência da Terra à roda, que permite que a roda gire (Tsing, 1997). Acresce que os termos indigenização e nativização sugerem um tipo de canibalismo cultural, ou, se se preferir, uma ingestão do outro, que transforma quer o canibal, quer o canibalizado. Esta associação entre modernidade e indigenização, nativização e canibalismo parece contradizer a associação convencional destes termos com o tradicional e o primitivo. Mas visto que considero a tradição como sendo a invenção da modernidade, como fazendo parte da visão que a modernidade tem da sua própria ruptura com o passado, gosto das contradições que estes termos sugerem. A indigenização lembra-nos que a modernidade implica um esquecimento das origens, um reivindicar de práticas culturais de outras paragens como se fossem as nossas próprias, a tal ponto que a história do seu viajar, muitas vezes, se perde.

Vou agora centrar-me em alguns exemplos de indigenizações que produziram modernismos diferentes: primeiro, o modernismo de Tayeb Salih, um escritor pós-colonial do Sudão que indigeniza o modernismo ocidental de Joseph Conrad; e, seguidamente, o modernismo de pintores modernos que viveram em Paris, em particular Pablo Picasso e Mary Cassatt, que nativizaram as “artes em viagem” de África e do Japão. 


\section{Tayeb Salih, modernista árabe: a indigenização de Conrad}

A imagem de ficar à escuta de duas mãos a bater palmas permite-nos incluir o brilhante romance pós-colonial de Tayeb Salih, Season of Migration to the North (Época da migração para norte), no cânone dos modernismos do século XX. Trata-se de um dos mais célebres romances contemporâneos escritos em árabe, da autoria daquele que é o maior escritor sudanês. Escrita durante o seu exílio em Beirute, a obra foi publicada em 1967, sendo a versão inglesa de $1969 .{ }^{\circ}$ O romance, que em parte é uma resposta à obra de Conrad Heart of Darkness (O coração das trevas), inverte a viagem de Kurtz da Europa para África. Mustafa Sa'eed é um notável prodígio sudanês que viaja do Sul para o Norte no início do século XX, rumo ao coração da metrópole colonial - primeiro para Cartum, depois para o Cairo e, finalmente, para Londres e Oxford. Tal como em Heart of Darkness, a história de Mustafa é, quase toda ela, contada por um narrador principal que, a exemplo do narrador Marlow e de uma forma ainda mais clara do que este, se torna um narrador não fiável. Ainda mais do que o romance de Conrad, Season of Migration to the North põe em movimento uma narrativa de indeterminação, de mistérios, mentiras e verdades, de eventos filtrados pela perspectiva de múltiplos narradores sucessivamente decorrentes uns dos outros, de complexas tapeçarias de motivos e símbolos entretecidos, de uma ironia difusa. ${ }^{9}$ Esteticamente falando, o romance de Salih insere-se no alto modernismo, afastando-se ainda mais do que o romance de Conrad das convenções do realismo. ${ }^{10}$

Da mesma forma que Kurtz excedeu as expectativas enquanto agente colonial, Mustafa é um grande êxito na Grã-Bretanha. É aí que vai acumulando graus académicos e se torna o preferido da esquerda britânica, escrevendo livros e aconselhando ministros sobre questões económicas e o desenvolvimento no Império. Numa relação de amor-ódio com a cultura que o exotiza, transforma-se no "homem inglês negro", infectado pela doença daqueles com quem vive, tal como, no Congo, Kurtz se havia tornado nativo. Seduz dezenas de mulheres brancas, caçando-as como se fossem presas, levando duas ao suicídio e assassinando, numa orgia sado-

\footnotetext{
${ }^{8}$ Para uma discussão da comunidade de exilados e escritores de que Salih fez parte em Beirute, ver Amyuni, 1985: 11-25; Sadgrove, 1997. Para discussões seleccionadas sobre o romance, ver especialmente Amyuni, 1985, produzido em Beirute; Abbas, 1974; Geesey, 1997; Gibson, 2002; Harlow, 1979; Hassan, 2003; Makdisi, 1992; e Shaheen, 1985.

9 Sobre a relação do romance com Heart of Darkness, ver sobretudo Shaheen, 1985.

${ }^{10}$ Para uma discussão de Season of Migration to the North e outros romances árabes contemporâneos (especialmente da autoria de escritores libaneses) como fazendo parte de um "modernismo árabe”, ver Makdisi, 1995:104-05.
} 
masoquista, a última delas, com quem se havia casado. ${ }^{11}$ Num acesso de culpa tipicamente liberal, o tribunal inglês aplica-lhe uma pena leve, deixando-se levar pelo mito da vítima colonizada e negando-lhe, assim, a dignidade do livre arbítrio e da responsabilidade moral pelos próprios actos. Revoltado, Mustafa migra de novo para o Sudão e escolhe uma aldeia na volta do Nilo, onde um dia aparece como que saído do nada. Aí começa a comprar terras, cultiva-as, casa com uma mulher local, e é parcialmente aceite como o estranho com um passado escondido que não partilha com ninguém. Um dia, depois de se certificar de que os seus assuntos estão todos em ordem, desaparece misteriosamente. Os aldeões presumem que se terá afogado nas cheias sazonais do Nilo, acidentalmente ou com a intenção de se suicidar, mas em Cartum também surge o boato de que terá regressado à Grã-Bretanha em segredo. No penúltimo capítulo do romance, o narrador abre a sala secreta que Mustafa mantivera escondida de toda a gente. A sala é uma réplica, construída no deserto, de uma biblioteca de cavalheiro britânico, onde não faltam centenas de livros e uma lareira sobre a qual pende um retrato da sua esposa branca falecida. Abalado pelo choque e num acto de desespero, o narrador vai nadar no Nilo em direcção à costa norte e, apesar de ter escolhido viver e não morrer afogado, o romance deixa-nos suspensos, tão inseguros do seu destino final como do de Mustafa.

Numa entrevista, Salih explica o estado de espírito de Mustafa como uma espécie de vingança pós-colonial sexualizada. "Na Europa", observa Salih, "existe a ideia de nos dominar. Essa dominação encontra-se associada ao sexo. Falando em termos figurados, a Europa violou a África de uma forma brutal. Mustafa Sa'eed, o herói do romance, costumava reagir a essa dominação com uma reacção oposta, que continha em si um elemento de busca de vingança. Nas suas violentas conquistas femininas, ele quer infligir à Europa a degradação que esta havia imposto ao seu povo. Ele quer violar a Europa num sentido metafórico" (Berkley e Ahmed, 1982: 15-16).

São muitas as interpretações que partem do princípio de que a perspectiva de Mustafa é também a de Salih. Mas, em última análise, o romance recusa oposições binárias simplistas, tais como as de Norte/Sul, colonizador/colonizado, modernidade/tradição. Em vez disso, Salih desvela a relação dinâmica de oposições tanto na Grã-Bretanha como no Sudão e põe por terra, em particular, a associação entre modernidade e Ocidente, por

${ }^{11}$ Sobre a "hiper-masculinidade" de Mustafa e a sua relação com o colonialismo, vide Gibson, 2002; Hassan, 2003. 
um lado, e, por outro lado, entre tradição e África. Ao estabelecer um distanciamento irónico entre ele próprio, o narrador e Mustafa, Salih põe a claro o modo como a "tradição" se encontra sempre sujeita a um processo de mudança e como a "modernidade", ao contrário do que aparenta, nunca é uma rejeição total do passado. Norte e Sul não são opostos, antes se constroem mutuamente, existindo numa relação conjuntural que se dá tanto entre nações como dentro de cada nação. A diferença sexual e a sexualidade são as forças que aniquilam a ilusão da diferença absoluta. Salih indigeniza o tropo conradiano da viagem rumo ao coração da alteridade, de forma a pôr a claro as trevas da casa própria. Na narrativa de Conrad, o avanço do barco a vapor pelo rio Congo acima denuncia a hipocrisia do imperialismo europeu (ou pelo menos do belga) em terras do Congo; no romance de Salih, a viagem para norte põe a descoberto, não apenas a doença do Norte, mas também a brutalidade da tradição na aldeia sudanesa junto ao Nilo. Para compreender o romance neste sentido, temos de estar sintonizados com a difusa ironia modernista e com a sua subtil desmontagem da ilusão, tanto no Norte como no Sul.

A aldeia do romance não é como o narrador e Mustafa a imaginam - um lugar imutável, singelo e afável. Há sinais de mudança por toda a parte, representados sintomaticamente no romance pela cadência constante do "matraquear dos motores de bombear água", que vieram substituir as antigas rodas das noras. Além disso, a "violação" praticada por Mustafa através da sedução de mulheres brancas no Norte tem contrapartida numa aterradora violação ocorrida na aldeia e sancionada pela tradição. A viúva de Mustafa, Hosna, uma mulher completamente "moderna" para o contexto da aldeia, recusa-se a aceitar os pretendentes e, em vez disso, dá a conhecer o desejo que sente pelo narrador. Chega mesmo a propor ao pai do narrador que mande o filho casar-se com ela. A mãe do narrador fica escandalizada: "Mas que desavergonhada! Assim se vê o que é uma mulher moderna!" (Salih, 1997: 123). Receoso do desejo que ele próprio sente por Hosna, o narrador acede a fazer algo de que discorda profundamente: aborda Hosna em nome de Wad Rayyes, o velho devasso da aldeia e amigo íntimo do seu avô, que está determinado a casar-se com ela. $\mathrm{O}$ amigo do narrador diria, mais tarde, a este: "O mundo não mudou tanto quanto tu pensas [...] Algumas coisas mudaram - bombas de água em vez de noras, arados de ferro em vez dos de madeira, rádios, carros, as nossas filhas a frequentar a escola, aprender a beber uísque e cerveja em vez de arak e vinho de milhete e, mesmo assim, está tudo na mesma [...] As mulheres pertencem aos homens e um homem é sempre homem, mesmo que já esteja decrépito (Salih, 1997: 99-101). 
A modernização das rodas das noras é coisa que ainda se tolera, mas mulheres modernas é que não. O resultado é catastrófico, dilacerando o exterior aparentemente plácido e imutável da aldeia, para revelar a brutalidade no seu interior. Hosna é obrigada a casar-se e consegue defender-se dos ataques do novo marido até à noite em que os aldeões ouvem os seus gritos e nada fazem para intervir, vindo depois a encontrar os dois, mortos e cobertos de sangue. Hosna fez o que dissera ao narrador - que mataria Wad Rayyes se fosse forçada a casar-se com ele. Em seguida, suicidou-se. A aldeia, segundo Salih, é um espaço de modernização parcial, uma modernidade em vias de um crescimento que não inclui raparigas e mulheres, nem as instituições familiares. A violação não é apenas uma metáfora para a exploração colonial e a vingança pós-colonial. A violação é também o que acontece quando "as mulheres pertencem aos homens". A maneira de ser tipicamente citadina de Hosna e a sua modernidade revelam-se provocantes não só para o narrador, que tem medo de agir, mas também para a personagem do velho, cujo desejo de possuir Hosna parece ser uma alegoria da resistência à própria modernidade. Para que não se considere o acto de Hosna como uma simples importação dos costumes ocidentais para dentro da aldeia, a reacção da esposa mais velha de Wad Rayyes ao relato da morte dele constitui um aviso arrepiante: "Deixá-lo ir!", diz ela, e no funeral "soltou estridentes gritos de alegria" (Salih, 1997: 128). Na aldeia, as raízes da modernização baseada na diferença sexual residem no sofrimento das mulheres e na sua ânsia de se libertarem da tirania existente no interior da família.

Numa desconstrução ainda mais aprofundada da oposição binária entre Norte e Sul, Salih liga a tirania com base na diferença sexual existente na aldeia ao domínio do Norte árabe do Sudão sobre o Sul não-árabe, invocando para tanto a existência de escravatura no país. A mãe de Mustafa, segundo nos é dito a dada altura, era uma escrava originária do Sul. Além disso, Wad Rayyes presenteia os amigos com a história de como "raptou uma escravazinha de um lugar a jusante dali", e de como se deliciava a violá-la vezes sem conta (Salih, 1997: 74). O facto de os amigos se rirem, deleitados, ao ouvir a sua história obscena, apenas dias antes de ter violado Hosna, intensifica a denúncia irónica que o romance faz da violência ocultada pela aparência pacata da aldeia. Desta forma, Salih indigeniza o projecto de Conrad em Heart of Darkness. Muito à semelhança da forma como Conrad pôs a descoberto a hipocrisia da civilização europeia, Salih denuncia a brutalidade escondida na relação ambivalente da aldeia com a modernidade e a sua recusa em incluir no seu futuro a segurança e liberdade das mulheres. 


\section{Picasso como modernista europeu: a indigenização da arte africana}

A importância da escultura africana para Pablo Picasso é bastante conhecida. No entanto, e no quadro daquilo que, de um modo geral, nos diz a história da arte, a arte de África permanece "primitiva" e "tribal", não sendo considerada ao mesmo nível das "belas artes". Já foi referido por especialistas da realidade cultural africana que os objectos que, no início do século XX, tanto influenciaram Picasso e muitos outros artistas não eram antigos, pois tinham sido criados durante a expansão imperial europeia em África, no decurso do século XIX (Rubin, 1984a: 21). Os mesmo autores referem também que a inovação e a expressão individuais a partir de convenções comuns eram frequentemente bastante apreciadas dentro das várias culturas às quais as máscaras e esculturas se destinavam (tal como a estética ocidental valorizava as variações individuais do motivo da Virgem com o Menino) (Rubin, 1984a: 3-4, 20-21). Contudo, as oposições binárias civilizado/primitivo, branco/negro, artista/artesão, arte/magia persistem hoje em dia, contribuindo para o mito difusionista eurocêntrico segundo o qual a Europa busca a inovação, o Resto busca a imitação; a Europa é moderna, o Resto é matéria-prima para a modernidade e o modernismo da Europa. ${ }^{12}$ Pela minha parte, proponho antes que Picasso (e não só) indigenizou a arte africana e que o seu modernismo depende, em parte, da sua nativização da arte da África colonial que viu em Paris - no Musée d'Etnographie du Trocadéro, em lojas de objectos de arte e em estúdios de muitos outros artistas e escritores modernistas, no contexto de um fenómeno de moda a que se chamou "art nègre".

A primeira peça de arte africana a que Picasso prestou particular atenção foi uma estátua do Congo que Matisse comprou em 1906, a caminho do apartamento de Gertrude Stein, onde Picasso e outros a viram (Paudrat, 1984: 139-40). Cerca de seis meses mais tarde, enquanto se debatia para completar Les demoiselles d'Avignon, o seu revolucionário novo quadro retratando cinco prostitutas, Picasso visitou o Musée d'Etnographie du Trocadéro, em Paris, onde esteve sentado, sozinho, numa sala cheia de

\footnotetext{
${ }_{12}$ Em 1984, William Rubin foi responsável por uma exposição inovadora sobre "primitivismo" e arte moderna que teve lugar no Museu de Arte Moderna. Esta mostra de arte colocou lado a lado trabalhos de artistas como Picasso, Matisse, Gauguin, Giacommeti, Brancusi, Henry Moore, e muitos outros, contando com exemplos espantosos de máscaras e esculturas africanas, a maioria delas do século XIX. Apesar da crítica de Rubin aos termos "primitivo" e "tribal" e da utilização que faz dos termos "artista" e "obra de arte" para se referir à arte africana, a sua introdução ao volume primeiro do catálogo e o seu ensaio sobre Picasso mantêm-se ambivalentes no que se refere a conceder a artistas africanos a mesma dimensão autoral e estatuto que ele encontra em artistas ocidentais como Picasso. Ver a crítica de Gikanki a Rubin e a discussão sobre a inspiração que Picasso vai buscar à arte africana (Gikandi, 2003).
} 
objectos provenientes de África e da Oceania, empilhados à toa, uns em cima dos outros (Rubin, 1984b: 255). Mais tarde, diria a Malraux que essa experiência tinha sido transformadora, "uma revelação". "Naquele momento", disse, "apercebi-me do significado do quadro" (Rubin, 1984b: 242). O que o impressionou foi uma combinação de princípios estéticos e expressivos. Descreveu a arte que então viu como sendo simultaneamente "raisonnable" - isto é, conceptual - e "magicaux" - ou seja, catártica (Rubin, 1984b: 255). A propósito das suas estruturas ideográficas e reducionistas, afirmou:

Para mim as máscaras não eram meras esculturas. Eram objectos mágicos [...] intercessores [...] contra tudo - contra o desconhecido, contra os espíritos malignos [...] Eram armas - para proteger as pessoas de serem governadas pelos espíritos, para as ajudar a libertarem-se a si mesmas. Se dermos uma forma a estes espíritos [...] tornamo-nos livres. (apud Rubin, 1984b: 255)

Depois dessa experiência no museu, Picasso terminou rapidamente Les demoiselles d'Avignon, servindo-se de máscaras para completar as figuras do lado direito da composição. Referiu-se ao quadro como um exorcismo, presumivelmente do medo que sentia do corpo e da sexualidade da mulher. ${ }^{13}$

Ao fazer a transposição cultural da arte africana para o alto modernismo europeu, Picasso não se baseou numa cópia directa, da mesma forma que uma boa tradução não é, forçosamente, uma tradução literal. Pelo contrário, tal processo envolveu uma transplantação de princípios estéticos africanos para a sua própria produção criativa, transplantação facilitada pelos interesses de que Picasso já antes dava mostras e misturada com outras formas artísticas que ele adaptou para a sua pintura híbrida. ${ }^{14}$ Os historiadores da arte fizeram notar as fortes semelhanças entre as máscaras de Les demoiselles d'Avignon e certos tipos específicos de máscaras africanas, mas muitas dessas máscaras só apareceram em Paris muito depois de 1907, altura em que Picasso acabou de pintar o quadro (Rubin, 1984b: 262). Alguns dos objec-

\footnotetext{
${ }^{13}$ Rubin argumenta que, neste período, Picasso vivia particularmente assustado com as doenças venéreas, o que o levava a olhar para o corpo feminino com repugnância. Rubin afirma: "A coabitação de Eros e Tanatos em Demoiselles faz lembrar uma componente específica da psicologia de Picasso: o seu entranhado medo e aversão ao corpo feminino - que existia a par do seu intenso desejo e da sua idealização extática desse mesmo corpo" (Rubin, 1984b: 253-54).

${ }^{14}$ Rubin sublinha a natureza híbrida do quadro, apontando para a influência da tradição europeia do $\mathrm{nu}$, do primitivismo ibérico (evidente especialmente no rosto da mulher no lado esquerdo do quadro), da art nègre (incluindo a arte da Oceania), de Cézanne e de Gauguin (Rubin, 1984b: 242-57).
} 
tos que, de facto, Picasso viu em 1907 no Museu sugerem, pelo contrário, a indigenização tanto da estética como da natureza catártica dos objectos.

A colecção de arte africana de Picasso foi crescendo regularmente ao longo da vida do pintor, continuando a reflectir-se na sua arte à medida que esta ia evoluindo. O posicionamento de Picasso em relação a este tipo de arte foi, no entanto, contraditório. Por um lado, sustentava que "a escultura primitiva nunca foi superada" (Rubin, 1984a: 5). Mas, por outro lado, não estabelecia qualquer distinção entre a arte de África e a da Oceania nem nutria o mínimo interesse pelos artistas ou culturas de onde provinha essa arte, afirmando: "Tudo o que preciso de saber sobre África está nestes objectos" (Rubin, 1984a: 74). Afirmou ainda que "as esculturas africanas penduradas [...] nos meus estúdios são mais propriamente testemunhas do que modelos" (Rubin, 1984a: 17). De acordo com Rubin, a arte que Picasso coleccionou era de qualidade relativamente pobre. "Para Picasso, isso nada importava". Rubin recorda-se de Picasso lhe ter dito: "Não é preciso uma obra de arte para se fazer uma ideia" (Rubin, 1984a: 14). Numa palavra, Picasso não via os artistas de África como confrères, como seus pares. A indigenização que faz da arte deles com vista à produção de obras do alto modernismo assentava num "esquecimento" dos agentes e culturas dos colonizados, cuja arte - para usar as palavras de Rubin - ele "canibalizou" como "um aríete contracultural" apontado à sensibilidade estética burguesa dos Europeus (Rubin, 1984a: 7). A institucionalização das Belas Artes e o reconhecimento da História da Arte como disciplina no século XX são a recapitulação do desinteresse evidenciado por Picasso. Aquilo a que se chama "arte tribal" ou "arte primitiva" não atinge o estatuto, os recursos económicos ou a atenção crítica que o modernismo europeu recolhe. ${ }^{15}$ Dentro do mundo da arte, o alto modernismo de Picasso e de outros artistas ainda depende da oposição binária moderno/tradicional, o Oeste e o Resto, que serve de suporte ao difusionismo eurocêntrico.

\section{Modernismo impressionista: a indigenização do ukiyo-e japonês}

A modernidade japonesa contemporânea e o seu impacto na cultura de massas ocidental têm os seus antecedentes nas viagens das xilogravuras japonesas para o Ocidente realizadas 100 anos antes e no papel seminal que exerceram na produção do modernismo. William Rubin atribui a estas gravuras, bem como à art négre, a revolução na arte moderna que teve o seu

\footnotetext{
15 Para uma crítica mais aprofundada do tratamento da arte "primitiva" nas instituições académicas e museológicas do Ocidente, ver Price (1989) e Gikandi (2003).
} 
centro em Paris (Rubin, 1984a: 10). Já em 1985, W. H. Ketchem propunha de forma generalizada a ideia de que a influência da arte japonesa enformara a arte moderna do Ocidente:

De tal modo os artistas, e especialmente os artistas franceses, ficaram impressionados com a extraordinária qualidade da composição de linhas e volumes que caracteriza os trabalhos dos mestres japoneses que não é exagero algum dizer que muitas das inovações que rapidamente se sucederam e pelas quais passou a arte ocidental, guiada pelo génio francês, durante a presente geração, se deveram grandemente ao estudo consciente das obras-primas do Oriente. (apud Blood, 2003: 145)

O fenómeno ocidental de moda e atracção pelos objectos japoneses - apelidada japonisme, em 1872 - começou na década de 60 do século XIX, após o Almirante Perry ter imposto a abertura dos portos japoneses, e deu-se em simultâneo com o fim do Japão do Xogunato de Tokugava, com o crescendo da campanha de modernização do Japão do período Meiji, e com o consequente incremento do tráfego cultural entre o Oriente e o Ocidente. Os impressionistas e pós-impressionistas franceses alimentaram a chama do japonisme, fascinados pelas xilogravuras vindas de Edo e conhecidas como ukiyo-e, ou Mundo Flutuante. Estas gravuras tiveram um impacto vincado em artistas tão distintos como Lautrec, Monet, Degas, Van Gogh e Cassatt, não só no que diz respeito aos temas da sua pintura, mas sobretudo no que concerne às formas estéticas: veja-se, por exemplo, o uso japonês dos contornos recortados, a composição assimétrica, as poses extremamente estilizadas, as cores vivas e os padrões fortes ou decorativos, a dispersão das figuras, e o espaço alternadamente vazio ou muito preenchido. ${ }^{16}$ Vejam-se, por exemplo, algumas imagens de um dos favoritos daqueles artistas, o artista oitocentista Hiroshige. ${ }^{17}$ Van Gogh, para quem os Japoneses eram "selvagens", incorporou essa selvajaria nos seus últimos trabalhos (Rubin, 1984a: 2). Em alguns dos seus trabalhos, Van Gogh faz alusão directa aos seus intertextos japoneses, mas noutros a transposição das formas japonesas surge indigenizada, só reconhecível por especialistas.

\footnotetext{
${ }_{16}$ Quanto à história e estética do ukiyo-e, ver por exemplo Newsom, 2003; Kobayashi, 1997. Quanto ao impacto do ukiyo-e nos artistas ocidentais, ver Blood, 2003; Flynn, 1982; Biblioteca do Congresso; Palkovic; Rubin, 1984a: 10-11. Embora vários artistas já tivessem visto gravuras japonesas em lojas parisienses por volta da década de 1850, o Pavilhão Japonês na Exposição Mundial de Paris, em 1867, apresentou o ukiyo-e aos artistas de uma forma particularmente visível. Houve uma série de exposições de arte japonesa nas décadas de 70 e 80 do século XIX. Cerca de 725 gravuras ukiyo-e foram expostas na Ecole des Beaux-Arts, em 1890 (Pollock, 1998: 166). Ver ainda Blood, 2003; Flynn, 1982; e Pollock, 1998: 165-75.

${ }_{17}$ A respeito deste artista, vide Bickwell (1994).
} 
Contudo, longe de serem "selvagens", as xilogravuras do Mundo Flutuante constituíam verdadeiramente um significativo nicho de modernidade inserido na sociedade predominantemente feudal do Japão. O Xogunato de Tokugava, que governou de 1615 a 1868, era conservador, proibindo os contactos com o mundo exterior. No entanto, os xóguns concederam um certo grau de liberdade a uma pequena área da cidade de Edo, a sua capital secular, onde não se aplicavam as leis sumptuárias das castas que restringiam o modo de vestir, a alimentação e o comportamento das classes de mercadores e artesãos (Newsom, 2003: 28-29). Foi nesse pequeno espaço de liberdade anárquica, conhecido como "mundo flutuante", que os artistas do ukiyo-e evoluíram e floresceram. Aí produziram milhares de xilogravuras - uma forma avant la lettre de "arte na era da reprodução mecânica", por assim dizer, cujos autores, caracterizados pela individualidade e pela inovação formal, gozavam de um amplo reconhecimento dentro do Japão. A arte do Mundo Flutuante era feita por e para plebeus, o que veio quebrar, de forma radical, as convenções estéticas prevalecentes nas artes destinadas à Corte Imperial. Este tipo de arte constitui um modernismo muito próprio e circunscrito dentro do Japão feudal.

A abertura do Japão ao comércio durante o período Meiji revolucionou o sistema feudal do país e trouxe a arte do Mundo Flutuante - a pequena ilha de modernidade japonesa no meio de um vasto oceano feudal - para o Ocidente, onde foi indigenizado como meio de romper com as convenções do perspectivismo realista. Em 1890, uma exposição de centenas de gravuras ukiyo-e levou Mary Cassatt a fazer a sua suite revolucionária conhecida como The Ten, uma série em água-forte com ponta-seca exibida em 1891. Utamaro, com a especial atenção que dedicou à vida íntima das mulheres - sobretudo da gueixa, no mundo flutuante -, era o artista favorito de Cassatt. ${ }^{18}$ Esta não copiou Utamaro - como tinha literalmente copiado os mestres da arte europeia, durante o seu período de aprendizagem. Em vez disso, as formas de Utamaro e de outros artistas acabaram por se impregnar na sua arte. De facto, Cassatt nativizou a estética das xilogravuras japonesas nas suas próprias técnicas inovadoras de água-forte, criando assim uma mistura híbrida. Além disso, as representações japonesas do corpo feminino deram-lhe liberdade de acção para, pela primeira vez, trabalhar o género do nu. Eis aqui a "incomensurável interpenetração

${ }_{18}$ Ver Utamaro, de Kobayashi (1993);; Barter (1998a). Para uma discussão dos conhecimentos de Mary Cassatt e da sua colecção de xilogravuras japonesas, ver Barter, 1998b: 57-59, 81-84; Blood, 2003: 143-145; Hirschler, 1998: 185-86; e Pollock, 1998: 165-75. Sobre o impacto de Cassatt na aquisição de arte moderna e de gravuras japonesas por outros artistas e museus dos Estados Unidos da América, ver Hirshler, 1998. 
de culturas" de Glissant, que continuou a exercer um impacto transformativo também nos óleos de Cassatt durante a década de 90 do século XIX. Ao contrário de Picasso, cuja atitude perante a arte africana que indigenizava era, simultaneamente, de admiração e de desinteresse, Cassatt promoveu a superior qualidade artística dos seus precursores, os praticantes do ukiyo-e. Não só coleccionou xilogravuras, como tinha também dispostos, na sua casa, a Suite of Ten lado a lado com trabalhos de artistas japoneses. Além disso, instou os amigos a coleccionar ukiyo-e e teve uma influência primordial nas colecções museológicas americanas desta popular forma de arte japonesa. Depois de ver a exposição de gravuras japonesas em 1890, Mary Cassatt escreveu o seguinte à amiga Bertha Morisot, também ela uma artista do impressionismo: "A sério, não podes perder isto. Quem quiser fazer gravuras coloridas não pode sonhar com nada mais belo. Eu sonhei com isto e não penso em mais nada, a não ser nas cores em gravuras de cobre [...] Tens mesmo de ver as japonesas - vem logo que possas" (Pollock, 1998: 167; Biblioteca do Congresso: 6).

\section{Conclusão}

A modernidade e o modernismo ocidentais formaram, juntamente com a indigenização das práticas culturais de outros locais, um processo que foi, em grande parte, viabilizado pelo colonialismo. Inversamente, os povos colonizados indigenizaram a modernidade e o modernismo ocidentais. Não obstante a existência de diferenças significativas, o influxo e refluxo de formas culturais foram constitutivos da modernidade e do modernismo, tanto para os centros imperiais como para os centros colonizados. A modernidade não é - e ainda quero convencer disso aquela estudante de pós-graduação de Xangai - propriedade do Ocidente, algo que é comprado, vendido, ou imposto ao Resto. O modernismo não é simplesmente um conjunto de expressões estéticas produzidas nas capitais culturais da Europa, na Grã-Bretanha e nos Estados Unidos entre as décadas de 90 do século XIX e a década de 40 do século XX. Do mesmo modo, nenhum espaço do globo pode isolar-se das ideias, dos bens, tecnologias, práticas, e das pessoas "em viagem" oriundos de outros locais. Precisamos de uma nova geografia e de uma nova história da modernidade que não fiquem fechadas na circularidade da definição e do difusionismo eurocêntricos. Precisamos de uma nova gramática espacial para pensar a modernidade e o modernismo. Precisamos que estas tenham um âmbito global, comparativo, interdisciplinar e transhistórico, e que tenham na devida conta o mimetismo e a diferença culturais. Em vez do binarismo que opõe o modernismo ocidental aos tradicionalismos do Outro, precisamos de uma nova geografia que procure a relação dinâmica 
entre a modernidade e a tradição no interior de cada espaço específico, assim como o papel que outras culturas desempenham em cada interacção local da ruptura e da continuidade histórica.

Tradução de

Inês Martins Ferreira e Rui Pedro Almeida

Revisão de

João Paulo Moreira

\section{Referências bibliográficas}

Abbas, Ali Abdalla (1974), "Notes on Tayeb Salih: Season of Migration to the North and The Wedding of Zein", Sudan Notes and Records, 55, 96-60.

Abu-Lughod, Janet (1989), Before European Hegemony: The World System A.D. 1250-1350. New York: Oxford UP.

Amyuni, Mona Takieddine (org.) (1985a), Season of Migration to the North, by Tayeb Salib: A Casebook. Beirute: American University of Beirut.

Amyuni, Mona Takieddine (1985b), "Introduction", in Amyuni (org.), Season of Migration to the North, by Tayeb Salih: A Casebook. Beirute: American University of Beirut, 11-25.

Baker, Houston A., Jr. (1987), Modernism and the Harlem Renaissance. Chicago: University of Chicago Press.

Barter, Judith A. (org.) (1998a), Mary Cassatt: Modern Woman. Washington, D.C.: Harry Abrams Publisher.

Barter, Judith A. (1998b), "Mary Cassatt: Themes, Sources, and the Modern Woman", in J. Barter (org.), Mary Cassatt: Modern Woman. Washington, D.C.: Harry Abrams Publisher, 45-107.

Benjamin, Walter (1968), "On Some Motifs in Baudelaire”, in Hannah Arendt (org.), Illuminations: Essays and Reflections. Trad. Harry Zohn. New York: Schocken Books, 155-200.

Berkley, Constance E.; Ahmed, Osman Hassan (orgs.) (1982), Tayeb Salib Speaks: Four Interviews with the Sudanese Novelist. Trad. Berkley e Ahmed. Washington, D.C.: Embassy of the Democratic Republic of the Sudan.

Berman, Marshall (1988), All That Is Solid Melts into Air: The Experience of Modernity. New York: Penguin Books.

Biblioteca do Congresso, "Japan and the West: Artistic Cross-Fertilization - The Floating World of Ukiyo-e" (http://www.loc.gov/exhibits/ukiyo-e/japan.html).

Bicknell, Julian (1994), Hiroshige in Tokyo: The Floating World of Edo. San Francisco: Pomegranate Artbooks. 
Blaut, J. M. (1993), The Colonizer's Model of the World: Geographical Diffusionism and Eurocentric History. New York: Guilford Press.

Blood, Katherine L. (2003), "Ukiuo-e and Its Orbit: The Library of Congress Collections in Context”, in Iris Newsom (org.), The Floating World of Ukyo-e: Shadows, Dreams, and Substance. Washington, D.C.: Harry Abrams Publishers, 115-55.

Bradbury, Malcolm; McFarlane, James (orgs.) (1976), Modernism, 1890-1930. New York: Penguin.

Chakrabarty, Dipesh (2000), Provincializing Europe: Postcolonial Thought and Historical Difference. Princeton: Princeton UP.

Chakrabarty, Dipesh (2002), Habitations of Modernity: Essays in the Wake of Subaltern History. Chicago: University of Chicago Press.

Chatterjee, Partha (1999), The Partha Chatterjee Omnibus: Nationalist Thought and the Colonial World: A Derivative Discourse? (1986); The Nation and Its Fragments (1992); A Possible India (1997). Oxford: Oxford UP.

Clifford, James (1997), “Traveling Cultures”, in J. Clifford, Routes: Travel and Translation in the Late Twentieth Century. Cambridge: Harvard UP, 17-46.

Eisenstadt, Shmuel N. (org.) (2000), “Multiple Identities”. Special Issue of Daedalus, 129(1).

Eisenstadt, Shmuel N.; Schluter, Wolfgang (orgs.) (1998), “Alternative Modernities”. Special Issue of Daedalus, 127(3).

Flynn, Patricia (1982), "Visions of People: The Influences of Japanese Prints - Ukiyo-e upon Late Nineteenth and Early Twentieth Century French Art", http://www.yale. edu/ynhti/curriculum/units/1982/4/82.04.03.x.html

Frank, Andre Gunder (1998), ReORIENT: Global Economy in the Asian Age. Berkeley: University of California Press.

Friedman, Susan Stanford (2001), "Definitional Excursions: The Meanings of Modern/ Modernity/Modernism”, Modernism/Modernity, 8(3), 493-514.

Friedman, Susan Stanford (2003), "Modernism in a Transnational Landscape: Spatial Poetics, Postcolonialism, and Gender in Césaire's Cabier/Notebook and Cha's Dictée”, Paideuma, 32(1-3), 39-74.

Friedman, Susan Stanford (em preparação), Transnational Modernism.

Gaonkar, Dilip Paramedhswar (org.) (2001), Alternative Modernities. Durham: Duke UP.

Geesey, Patricia (1997), "Cultural Hybridity and Contamination in Tayeb Salih's Mawsim al-hijira ila al-Shamal (Season of Migration to the Nortb), Research in African Literatures, 28, 128-40.

Gibson, Brian (2002), "An Island unto Himself? Masculinity in Season of Migration to the Nortb", Jouvert 7(1).

Gikandi, Simon (2003), "Picasso, Africa, and the Schemata of Difference", Modernism/ Modernity, 10(3), 455-80. 
Gilroy, Paul (1993), The Black Atlantic: Modernity and Double Consciousness. Cambridge: Harvard UP.

Glissant, Eduard (1997), Poetics of Relation. Trad. Betsy Wing. Ann Arbor: University of Michigan Press.

Harlow, Barbara (1979), “Othello's Season of Migration”, Edebiyat 4(2), 157-75.

Hassan, Wail S. (2003), "Gender (and) Imperialism: Structures of Masculinity in Tayeb Salih's Season of Migration to the North”, Men and Masculinities 5(3), 309-24.

Hirshler, Erica E. (1998), "Helping 'Fine Things' Across the Atlantic: Mary Cassatt and Art Collecting in the United States”, in J. Barter (org.), Mary Cassatt: Modern Woman. Washington, D.C.: Harry Abrams Publisher, 177-211.

Huntington, Samuel P. (1996), The Clash of Civilizations and the Remaking of World Order. New York: Simon and Schuster.

Joshi, Priya (2002), In Another Country: Colonialism, Culture, and the English Novel in India. New York: Columbia UP.

Kobayashi, Tadashi (1993), Utamaro: Portraits from the Floating World. Trad. Mark A. Harbison. New York: Kodansha.

Kobayashi, Tadashi (1997), Ukiyo-e: An Introduction to Japanese Woodblock Prints. Trad. Mark A. Harbison. New York: Kodansha.

Makdisi, Saree S. (1992), "The Empire Renarrated: Season of Migration to the North and the Reinvention of the Present”, Critical Inquiry 18, 804-20.

Makdisi, Saree S. (1995), “'Postcolonial' Literature in a Neocolonial World: Modern Arabic Culture and the End of Modernity”, boundary 2 22(1), 85-115.

McNeill, William H. (1990), "The Rise of the West after Twenty-Five Years”, in Stephen K. Sanderson (org.), Civilizations and World System: Studying World-Historical Change. London: Sage, 304-20.

Mitchell, Timothy (org.) (2001), Questions of Modernity. Minneapolis: University of Minnesota Press.

Newsom, Iris (2003), "Introduction”, in Newsom (org.), The Floating World of Ukyo-e: Shadows, Dreams, and Substance. Washington, D.C.: Harry Abrams Publishers, 11-79.

Nicholls, Peter (1995), Modernisms: A Literary Guide. Berkeley: University of California Press.

Palkovic, Penny, “The Influence of Ukiyo-e on Van Gogh”, http:// www.barjwhit.com/ Ukiyoe.htm

Paudrat, Jean-Louis (1984), "The Arrival of Tribal Objects in the West: From Africa”, in William Rubin (org.), "Primitivism" in 20th Century Art: Affinity of the Tribal and the Modern. Vol. 1. Boston: Little, Brown, 125-78.

Pollock, Griselda (1998), Mary Cassatt: Painter of Modern Women. London: Thames and Hudson.

Price, Sally (1989), Primitive Art in Civilized Places. Chicago: University of Chicago Press. 
Rao, Velcheru Narayana; Shulman, David (2002), “Introduction”, in V. Rao; D. Narayana, The Sound of the Kiss. New York: Columbia UP, xv-xxv.

Rubin, William (1984a), “Modernist Primitivism: An Introduction”, in W. Rubin (org.), "Primitivism" in 20 th Century Art: Affinity of the Tribal and the Modern. Vol. 1. Boston: Little, Brown, 1-84.

Rubin, William (1984b), "Picasso", in W. Rubin (org.), "Primitivism" in 20 Century Art: Affinity of the Tribal and the Modern. Vol. 1. Boston: Little, Brown, 241-344. Sadgrove, Philip (1997), “Al-Tayyib Salih”, in Brian C. Cox, African Writers, vol. 2. New York: Charles Scribner's, 733-44.

Said, Edward W. (1983), "Traveling Theory”, in E. Said, The World, the Text, and the Critic. Cambridge: Harvard UP, 226-47.

Salih, Tayeb (1997), Season of Migration to the North. Trad. Denys Johnson-Davies. Boulder, Colorado: Lynn Reiner Publishers [1967].

Sanderson, Stephen K. (org.) (1995), Civilizations and World Systems: Studying World-Historical Change. London: Sage.

Scott, James C. (1998), Seeing Like a State: How Certain Schemes to Improve the Human Condition Have Failed. New Haven: Yale UP.

Shaheen, Mohanmmad (1985), "Tayeb Salih and Conrad", Comparative Literature, 22(1), 156-71.

Shohat, Ella; Stam, Robert (1994), Unthinking Eurocentrism: Multiculturalism and the Media. London: Routledge.

Spivak, Gayatri Chakravorty (2003), Death of a Discipline. New York: Columbia UP. Tsing, Anna (1997), “Transitions as Translations”, in Joan W. Scott; Cora Kaplan; Debra Keates (orgs.), Transitions, Environment, Translations: Feminisms in International Politics. London: Routledge, 253-72.

Tsing, Anna (2004), Friction: An Ethnography of Global Connection. Princeton: Princeton UP.

Wallerstein, Immanuel (1974), The Modern World-System: Capitalist Agriculture and the Origins of the European World-Economy in the Sixteenth Century. New York: Academic Press.

Wallerstein, Immanuel (1997), "Eurocentrism and Its Avatars: The Dilemmas of Social Science”. New Left Review, 226, 93-108.

Wang, David Der-wei (1997), Fin-de-Siècle Splendor: Repressed Modernities of Late Qing Fiction, 1849-1911. Stanford: Stanford UP.

Weatherford, Jack (2004), Genghis Kabn and the Making of the Modern World. New York: Three Rivers Press.

Williams, Raymond (1983), Keywords: A Vocabulary of Culture and Society. New York: Oxford UP [1976]. 